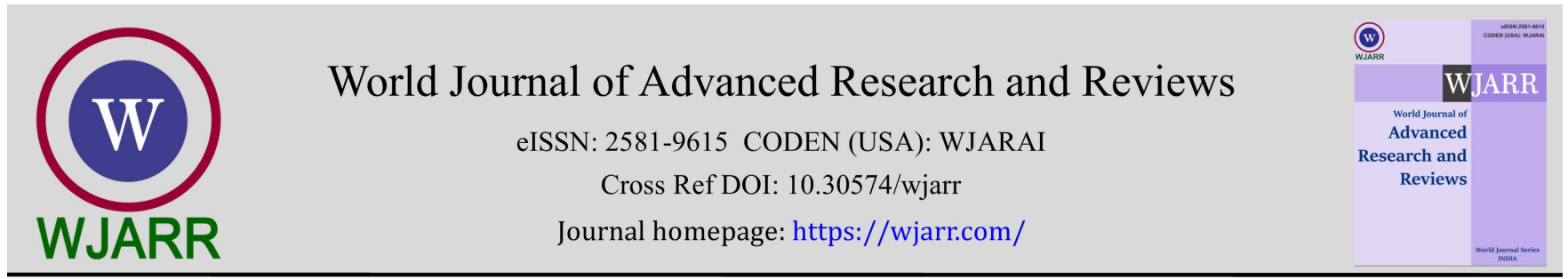

(RESEARCH ARTiClE)

\title{
The effect of income on regularity of paying contributions for independent National Health Insurance (NHI) participants post policy increased contributions in Muna regency, southeast Sulawesi province, Indonesia
}

\author{
Nani Hendryani, Suhadi * and I Made Christian Binekada \\ Postgraduate Masters in Public Health Study Program at Halu Oleo University Kendari, Indonesia.
}

World Journal of Advanced Research and Reviews, 2022, 13(02), 309-315

Publication history: Received on 11 January 2022; revised on 12 February 2022; accepted on 14 February 2022

Article DOI: https://doi.org/10.30574/wjarr.2022.13.2.0155

\begin{abstract}
The number of NHI Independent participants in Indonesia continues to increase despite the fact that it is not matched by the regularity of paying dues for independent NHI participants. The purpose of this study was to determine the effect of income on the regularity of paying dues for independent NHI participants after the increase in contributions in Muna Regency, Southeast Sulawesi Province. This type of research is quantitative research using a cross sectional study approach. The research sample was 98 people. Data was collected by means of interviews and observations. Data analysis was performed by Univariate and Bivariate. Presentation of data in the form of frequency distribution accompanied by explanations. The results showed that there was an effect of income on the regularity of paying dues for independent NHI participants after the contribution increase policy in Muna Regency, Southeast Sulawesi Province, with a value of $\mathrm{p}=0.034(\mathrm{p}<0.05)$. Conclusion; there is an effect of income on the regularity of paying dues for independent NHI participants after the contribution increase policy. Suggestion; It is necessary to develop an economic recovery strategy to increase people's income, in order to support the regularity of paying dues for independent NHI participants.
\end{abstract}

Keywords: Income; Regularity; Paying; Contributions; NHI

\section{Introduction}

Generally, the world's population suffers from illness and even death due to lack of access to basic health services provided by the government. This is supported by data that around 150 million people per year in poor and middleincome countries experience suffering due to the large health costs that must be incurred and every three people every second experience poverty due to the heavy health costs they bear [1]. The presence of the national health insurance program is seen as one of the main ways to achieve an increase in health status for the entire population of Indonesia by ensuring that all people can receive quality health services in accordance with the wishes and needs of the community, without experiencing financial difficulties [2].

Thus, to prevent obstacles to the availability of funds, it is important to develop a model of a health insurance system towards achieving universal health coverage [2]. In general, the Indonesian nation is ranked 101 out of 149 countries when viewed from the human resource development index, especially in the health sector. In Southeast Asia, the Indonesian nation is still relatively low, under Thailand, Malaysia, Vietnam, and Laos. If this condition is measured from the degree of public health, then the Indonesian nation is still classified as lagging behind. Thus, it is necessary to increase more serious attention from the government to improve services and national health insurance programs. In this case, the Government has a role in determining policies, monitoring, implementing, and fostering the NHI program

\footnotetext{
${ }^{*}$ Corresponding author: Suhadi

Postgraduate Masters in Public Health Study Program at Halu Oleo University Kendari, Indonesia.

Copyright (C) 2022 Author(s) retain the copyright of this article. This article is published under the terms of the Creative Commons Attribution Liscense 4.0.
} 
towards the independence of health services that are evenly distributed throughout the territory of the Republic of Indonesia [3].

To prevent delays in health services for the poor and underprivileged, the government has established a national health insurance program as a national flagship program. In achieving the program, the Government has established program regulations as stipulated in Law Number 40 of 2004 concerning the National Social Security System. As a legal forum for the implementation of national health insurance services, the government established a Social Security Administering Agency (SSAA), which includes two legal entities, namely SSAA Employment and SSAA Health.

In 2019, the Prakarsa Institute conducted a study with the aim of identifying the basic problems of the NHI budget deficit both at the national level and in six districts/cities in Indonesia. The problem of the NHI budget deficit at the national and regional levels has almost the same pattern. Based on the results of this study, indications of the problem of the NHI budget deficit are caused by various factors, including: 1) The burden of health services has soared beyond the source of income; 2) The amount of NHI premiums/contributions is low, far below the claims for the guarantees provided; 3 ) Weak transparency in the financial management of SSAA Health; 4) The participation coverage is not yet maximal, both from the Contribution Assistance Recipient (CAR) category, Non-Wage Recipient Participants (NWRP), and Wage Recipient Participants, as well as the lack of participant compliance in paying contributions, especially in the WNRP category; 5) The burden of health funding for catastrophic diseases continues to increase. Until September 2018 the burden of catastrophic disease has reached 22 percent of the total national health costs, which is Rp.14.5 trillion; 6) The first-level health facilities as the frontline have not yet fully functioned, namely still focusing on curative actions, not promotive and preventive services; and 7) inefficiency of tiered referrals at Health Facility Level [4].

Currently, in the Southeast Sulawesi Province, the number of NHI participants, both CAR and non-CAR, has reached $2,409,474$ people out of a total population of 2,632,939 or around $91.51 \%$. The number of CAR participants funded by the state spending revenue budget (SSRB) is 1,209,244 people. The CAR funded by the Regency/City Regional Expenditure Revenue Budget (RERB) is 547,697 people. CAR which is financed by the Provincial Expenditure Budget is 36,516 people, Wage Recipient Employees (WRE) are 308,417 people, WRE Private employees are 90,282 people, WNRP is 180,324 people and Non-Workers are 36,994 people [5]. Based on Universal Health Coverage (UHC) participation data, as of 31 December 2019, 10 Regencies/Cities in Southeast Sulawesi Province that have achieved UHC include Buton, South Buton, North Buton, Muna, West Muna, Wakatobi, Bau Bau, Bombana, Konawe. Islands and North Konawe with participation achievement above 97\% [6].

In the Muna Regency area, the number of NHI participants was recorded as of December 31, 2019 as many as 225,628 people. NHI CAR participants who received allocation of SSRB funds were 100,850 people, NHI CAR participants who received allocations of RERB Regency/city funds were 81,272 people. NHI CAR participants who received the allocation of Provincial RERB funds were 2,486 people. Meanwhile, the number of Civil Servant Wage Recipients is 30,014 people. Wages Recipients Private employees are 777 people. Non-Wage Recipient Workers as many as 6,255 people and NonWorkers as many as 3,974 people [7]. Muna Regency is one of the regencies that achieved UHC, but with the increase in NHI contributions since July 2021, people feel their inability to pay NHI contributions, this has an impact on noncompliance and regularity in paying contributions. Data as of October 31 shows that the total number of independent NHI participants was 6,454 with arrears status of 4,244 people, far more than the non-arrear status of 2,199 people [7].

The results of a preliminary survey conducted showed that several independent NHI participants experienced several problems, including the existence of independent NHI participants who were in arrears in paying their independent $\mathrm{NHI}$ contributions, as a result, when using health facilities they experienced problems because their NHI cards were inactive, there were arrears in payment of NHI contributions. for several months so that they feel burdened with the amount of fines in arrears of dues. Independent NHI participants feel that the increase in contributions set by the Government in July 2021 is very burdensome and is considered expensive, causing NHI Independent participants to not regularly pay dues. On the other hand, the lack of income due to the Covid-19 pandemic and high expenditure burdens have also caused NHI Independent participants to not regularly pay dues. The purpose of the study was to determine the effect of income on the regularity of paying NHI dues for Independent Participants after the Contribution Increase Policy in Muna Regency, Southeast Sulawesi Province.

\section{Material and methods}

The type of research used in this research is survey research using a cross sectional study approach. The research location is in Muna Regency, Southeast Sulawesi Province in 2021. The size of the research sample is 98 people. Determination of the sample size using the Slovin formula. The selection of the research sample was carried out by purposive sampling, namely the sample selection technique based on the considerations of the researcher. Data was 
collected by means of interviews and observations. Data analysis was performed by Univariate and Bivariate. Presentation of data in the form of frequency distribution accompanied by explanations.

\section{Results}

\subsection{Univariate Analysis}

\subsubsection{Family Income}

Family income is the amount of income or the total family income obtained from the results of daily work as measured in currency units in 1 month's income by households. The distribution of respondents according to the income of independent NHI participants is presented in table 1.

The ability to pay for health is the amount of funds that can actually be allocated to finance the health in question. The ability to pay the contributions of independent NHI participants is categorized into capable and unable, as presented in table 1.

Table 1 Distribution of respondents according to the income of independent NHI participants after the policy of increasing NHI contributions in Muna Regency, Southeast Sulawesi Province

\begin{tabular}{|l|c|c|}
\hline \multicolumn{1}{|c|}{ Income } & Amount (n) & Percentage (\%) \\
\hline Enough & 13 & 13 \\
\hline Not enough & 85 & 87 \\
\hline Total & 98 & 100 \\
\hline \multicolumn{2}{|c|}{ Source: Primary Data Year 2021 }
\end{tabular}

Based on Table 1, it shows that from 98 respondents (100\%) there are 13 respondents (13\%) who have sufficient income in paying contributions and as many as 85 respondents (87\%) have less income in paying contributions.

\subsection{Regularity of Paying Dues}

The regularity of paying National Health Insurance contributions in this study is the timeliness of payment of National Health Insurance contributions made by respondents, where the payment time has been determined no later than the 10th of each current month as stipulated in the Presidential Regulation of 2021. The distribution of respondents is based on regularity. paying the dues of independent NHI participants, is presented in table 2.

Table 2 Distribution of respondents according to the regularity of paying NHI contributions for independent participants after the contribution increase policy in Muna Regency, Southeast Sulawesi Province.

\begin{tabular}{|l|c|c|}
\hline Regularity of Paying Dues & Amount (n) & Percentage (\%) \\
\hline Regular & 44 & 45 \\
\hline Irregular & 54 & 55 \\
\hline Total & 98 & 100 \\
\hline \multicolumn{2}{|c|}{ Source: Primary Data in 2021 }
\end{tabular}

Based on Table 2, it shows that from 98 respondents (100\%) there are 44 respondents (45\%) have regularity in paying $\mathrm{NHI}$ contributions and as many as 54 respondents (55\%) do not have regularity in paying NHI contributions. 


\subsection{Bivariate Analysis}

\subsubsection{The effect of income on the regularity of paying NHI contributions for independent participants}

Table 3 The effect of income on the regularity of paying NHI contributions for independent participants after the policy of increasing contributions in Muna Regency, Southeast Sulawesi Province

\begin{tabular}{|c|c|c|c|c|c|c|c|}
\hline \multirow[t]{3}{*}{ Income } & \multicolumn{4}{|c|}{ Regularity of Paying Dues } & \multirow{2}{*}{\multicolumn{2}{|c|}{ Amount (n) }} & \multirow{3}{*}{$P$ Value } \\
\hline & \multicolumn{2}{|c|}{ Regular } & \multicolumn{2}{|c|}{ Irregular } & & & \\
\hline & $\mathbf{n}$ & $\%$ & $\mathbf{n}$ & $\%$ & $\mathbf{n}$ & $\%$ & \\
\hline Enough & 2 & 15 & 11 & 85 & 13 & 100 & \multirow{3}{*}{0,034} \\
\hline Not Enough & 42 & 49 & 43 & 51 & 85 & 100 & \\
\hline Total & 44 & 45 & 54 & 55 & 98 & 100 & \\
\hline
\end{tabular}

Table 3 shows that of 13 respondents (100\%) who have sufficient income, there are 2 respondents (15\%) who have regularity in paying NHI contributions, and as many as 11 respondents (85\%) do not have regularity in paying contributions. NHI. Meanwhile, of the 85 respondents (100\%) who have less income, 42 respondents (49\%) have regularity in paying $\mathrm{NHI}$ contributions and 43 respondents (51\%) do not have regularity in paying NHI contributions.

The results of the chi square test obtained a value of $p=0.034(p>0.05)$ meaning Ho is rejected. This shows that there is an effect of income on the regularity of paying NHI contributions for independent participants after the contribution increase policy in Muna Regency, Southeast Sulawesi Province.

\section{Discussion}

Since NHI was implemented on January 1, 2014, the financing for health services has only been sourced directly from the government through SSRB and RERB allocations, and community funding has been sourced through the payment of NHI premiums in accordance with the class of citizenship owned by each citizen. In its development, the implementation of NHI faced problems in the form of a deficit of NHI funds. To identify these problems, one of the associations under the name Prakarsa conducted a study to explore the root causes of the NHI deficit at the national and six regencies/cities in Indonesia. The problem of the NHI deficit at the national and regional levels has almost the same pattern. Based on the results of this study, indications of the problem of the NHI deficit stem from various factors, including: 1) the swelling burden of health services, exceeding the source of income; 2) contribution contributions are still low, far below the claim against the guarantee provided; 3) lack of transparency over the financial management of SSAA Health; 4) the coverage of participation is not yet maximized, both from the CAR category, Non-Wage Recipient Participants, and Wage Recipient Participants, as well as the lack of participant compliance in paying contributions, especially in the Non-Wage Recipient Participant category; 5) the burden of health funding for catastrophic diseases continues to increase. In September 2018 the burden of catastrophic disease reached 22 percent of total health costs or 14.5 trillion rupiah; 6) First-level health facilities as the front line have not yet fully functioned, namely still focusing on curative actions, not promotive and preventive services; and 7) inefficiency of tiered referrals in advanced health facilities [4]

Family income is the amount of income or income earned by a family or person in the current month according to the minimum wage set by the local government. The amount of a person's income will affect the ability to pay NHI contributions. The higher a person's income, the higher public awareness of insurance and paying contributions. Likewise, the amount of income they have plays a role in determining a person or family for regularity in paying National Health Insurance contributions. A person's income plays an important role in the high awareness of a person to regularly pay contributions to the National Health Insurance. Likewise, a low amount of income will reduce the regularity of the community in paying the National Health Insurance dues because the community will prioritize other needs rather than paying the NHI contributions. On the other hand, people who have high incomes and have middle to upper welfare levels have a high level of regularity in paying the National Health Insurance contributions [8].

If you look at the research findings as presented in table 1, it is found that, in general, independent NHI participants who have less income, are more numerous than independent NHI participants who have sufficient income to pay NHI contributions. This shows that the lower the respondent's income, the lower the regularity of paying NHI contributions. Conversely, the higher the income, the higher the regularity of paying NHI contributions. This happens because income 
affects the ability of participants to pay NHI contributions. Where with this amount of income, independent NHI participants will prioritize their main needs in daily life such as eating, drinking and clothing, but when their income is fulfilled, they will allocate income for health service needs. Another factor that plays a role in encouraging independent NHI participants to regularly pay NHI contributions is the aspect of health services needed. If this is in accordance with the value of the benefits and even exceeds their wishes, then independent NHI participants will continue to strive to regularly pay NHI fees, but on the other hand if the health services needed are not in accordance with the benefits they receive, independent NHI participants will become disorganized to perform payment of NHI dues.

The biggest challenge faced by the community during the Covid-19 pandemic is the existence of government policies through the imposition of restrictions on community activities, this has an impact on people's income where people cannot work as normal so that people who do not have a fixed income can experience a decrease in income. The low income of the community during the Covid-19 era will force a person to change spending patterns from normal needs to very urgent needs, especially eating, drinking, and clothing. This change in spending patterns can negate and even delay public compliance with regular payment of NHI contributions. Difficulties in obtaining sufficient income are not only experienced by informal sector workers, but also formal sector actors as a result of limited work activities in finding sources of income. If this is the case, with many people who do not regularly pay NHI contributions, this will reduce the amount of NHI's financial income as a result, the financing of health services at health facilities will be delayed or even reduced as usual. This will make it difficult for health service providers to carry out financial management engineering so that the operationalization of health services continues. In fact, in health services, if there are people who do not pay NHI contributions regularly, the patient will be denied health services until the patient has settled the arrears in payment. This condition is a dilemma for health service providers and even more so for the community.

From the results of statistical tests using Fisher's Exact Test, obtained p-value $=0.034(\mathrm{p}<0.05)$, so H1 is accepted and $\mathrm{HO}$ is rejected. This shows that there is an influence of income on the regularity of paying dues for independent NHI participants after the policy of increasing contributions in Muna Regency, Southeast Sulawesi Province. The results of this study are in line with research conducted by [9] which says that there is a relationship between high income and the demand for health care, especially in terms of health services. Research [10] says that in low-income communities, they will meet the needs of goods first, after the need for goods is fulfilled, they will consume health. Health care costs generally increase with increasing income. People with high incomes tend to be more frequent and more extensive in health services. People with high incomes are also more likely to check and maintain their health than people with low incomes. Research [11]. Says that the ability to pay is related to income level and can influence the patient's determination in choosing the treatment that can maximize satisfaction and benefits. Mudayana who states that family income affects the patient's ability to pay for health services that have been provided, if the patient's income is still lacking then they assume that they cannot afford health services [12]. If a person has an increasing income, of course, the ability to pay health contributions will also increase. This is because the allocation of health costs is greater so that it will provide a greater ability to pay to pay the tariff for these health services [9]. Research [13] in the working area of the Batalaiworu Health Center, it was found that there is a relationship between income and participant compliance in paying SSAA independent contributions.

The results of this study are also in line with research [14] which shows that there is a relationship between income and regularity in paying NHI contributions in West Jakarta, because high income levels are more obedient in paying NHI contributions than low income levels. In line with research [15] that the level of income has a relationship with the regularity of independent participants in paying contributions. NHI Independent participants with low incomes and irregular in paying contributions are due to participants preferring to use their money for other necessities of life rather than paying contributions. Meanwhile, respondents who have low incomes but regularly pay NHI contributions because the payment of national health insurance contributions is paid by those closest to them, such as family and close relatives.

The findings also show that there are 13 respondents who have sufficient income, with details of 3 respondents working as farmers, the rest 10 respondents have jobs as entrepreneurs, but some respondents have less income with job categories as Labor, Honorary, and Housewives. Respondents who work as laborers generally earn uncertain income, but it depends on the number of days they work based on the daily payroll system, so conditions like this allow them not to have a steady income. But with work as farmers, they can have income in a certain period when the harvest is complete. Likewise, for respondents who have a job as an office honorary, the income category is quite low, below one million rupiah per month is not enough to meet their main needs. Likewise, for respondents who have self-employed jobs, low income is always a reason for them to be irregular in paying their independent NHI contributions.

The availability of sufficient funds owned by the community conceptually has an influence on regularity in paying Independent Contributions, but the magnitude of the impact caused by the Covid-19 problem has resulted in a decrease 
in people's income, the regularity of paying NHI contributions becomes irregular. Therefore, the role of the government as the state administrator is needed to formulate policies on funding sources for NHI during the COVID-19 period, primarily to help the underprivileged to remain served in health care facilities when they are sick. On the other hand, efforts are needed to increase people's income through social assistance and relief from the payment of the Independent NHI Contribution. When viewed from the income ability of independent NHI participants, they generally have incomes below the district minimum wage, this income is still relatively low so that many independent NHI participants prioritize the main funding for daily needs such as food, drink and clothing, and eliminate the payment of independent NHI contributions.

The findings from this study also show that some independent NHI participants who have a fairly high income tend to be regular in paying NHI contributions. Those with high incomes are always obedient in paying NHI contributions because they are well aware that health services are very important and needed when they are sick. But on the other hand, there are still some people who have high incomes but are reluctant to pay NHI contributions, because in their opinion that paying NHI contributions every month is not an urgent need at this time. This picture shows that some people do not understand and are aware of the importance of health financing in the future and there is still a lack of socialization of the NHI program based on the principle of mutual help.

If you look at the reality, with the low regularity of independent NHI participants in paying NHI contributions, it is necessary for the relevant parties to work together through cross-sectoral collaboration to improve coordination and educate the public so that they are regular in paying NHI contributions. Increasing the role of the government in an effort to increase people's income through social assistance affected by COVID-19 so that they have the ability to pay NHI contributions. Another program is to create job opportunities and provide skills training for the community so that they can increase their income through independent entrepreneurial activities to increase people's income. Likewise, there is a need to socialize the amount of NHI contributions for the poor, to provide an understanding of the NHI crosssubsidy system and fines for arrears of NHI contributions.

\section{Conclusion}

There is an effect of income on the regularity of paying dues for independent NHI participants after the contribution increase policy. Suggestion; It is necessary to develop an economic recovery strategy to increase people's income, to support regularity in paying contributions for independent NHI participants.

\section{Compliance with ethical standards}

\section{Acknowledgments}

The author would like to thank the Dean of the Faculty of Public Health, Halu Oleo University, who has provided support to the writing team so that this research can be carried out properly. Furthermore, the team of authors would like to thank all those who have helped until the end of this research.

\section{Disclosure of conflict of interest}

All authors in the making of this scientific article have no conflict of interest.

\section{Statement of informed consent}

All informants/respondents involved in this study have stated their consent as informants/respondents to be interviewed and provided information/information in accordance with research needs.

\section{References}

[1] Hasibuan R. Overview..Response of JKN participants..Regarding Increase..Premiums at..Dua..Medan City Health Center..In 2019," Contag. science. J. of..Public Heal. and..Coastal Heal. 2019; 1(2): 108-120.

[2] Lozano R, et al. Measuring universal health coverage based on an index of effective coverage of health services in 204 countries and territories, 1990-2019: a systematic analysis for the Global Burden of Disease Study 2019," Lancet. 2019; 396(10258): 1250-1284.

[3] Wijaya, et al. JKN-KIS BPJS Health Participant Satisfaction Level in Palembang City," Exist J. 2018; 13(2): 81-92. 
[4] Aidha, C.C. "National Health Insurance Deficit. Proposed Alternative for Sustainable Funding," Jakarta. 2020.

[5] BPS Muna, "Muna Regency in Figures," Raha. 2020.

[6] Health Office S.S.P, Southeast Sulawesi Health Office Profile 2019, Kendari. 2019.

[7] Muna Health Office. Muna District Health Office Profile 2019. Raha. 2020.

[8] BPJS RK. Regulation of the Health Social Security Administering Body Number 4 of 2014 concerning Procedures for Registration and Payment of Individual Participants of the National Health Social Security Administering Body. Republic of Indonesia. 2014; 7.

[9] Sihaloho EN. Determinants of Willingness to Pay Contributions for Independent National Health Insurance Participants in the Work Area of the Semarang City Health Service," Jur. Public Health, Fak. Sports Science, Univ. Semarang State. 2015; 1(3): 193-201.

[10] Agustina, et al. J, Analysis of the Ability and Willingness of PBPU Patients to Pay National Health Insurance Contributions, Wind. heal. J. Health. 2021; 4(3): 238-247.

[11] Fauziyyah I. Analysis of ATP (Ability to Pay) and WTP (Wllingness to Pay) on Decisions to Determine Health Insurance Contribution Classes for Angkot Drivers in the city of Semarang, "Faculty of Public Health, State University of Semarang. 2016.

[12] Mudayana A.A. Analysis of Ability and Willingness to Pay for Inpatients at Pku Muhammadiyah Bantul Hospital," J. Kesehat. Masy. (Journal of Public Heal. 2015; 9(1): 45-52.

[13] Rismawati, et al. Factors Relating to the Decision to Pay BPJS Mandiri Contributions in the Work Area of the Batalaiworu Health Center, Batalaiworu District, Muna Regency," JIMKESMAS (Journal of Science. Student Health. Community). 2017; 2(8): 1-10.

[14] Ghassani M.T. The Effect of Product Quality and Price on Buying Interest of Milkfish Juwana Vaccum Through Consumer Satisfaction as an Intervening Variable (Case Study on Customers of PT. Bandeng Juwana Elrina Semarang), DIPONEGORO J. Soc. Politic. science. 2017; 1-8.

[15] Agustina Z.A, Izza N. The Relationship of the One Family (Collective) Payment System to Class Transfers and Participation Classes and Compliance with the Payment of Social Security Contributions in Malang Regency, Bul. researcher. Sis. Health. 2019; 22(1): 44-53. 